\title{
California Enacts Drug Pricing Transparency Bill
}

The Mercury News is reporting that California governor Jerry Brown signed a bill Monday making drug pricing more transparent (1). The legislation requires pharmaceutical companies to notify health insurers and government health plans at least 60 days before making price hikes and explain the reason for the increase. The pharmaceutical industry had lobbied hard against the measure, worried that it could become a national model and the first big step toward price controls. "The essence of this bill is pretty simple," Brown told a room filled with supporters of Senate Bill 17. "Californians have a right to know why their medical costs are out of control, especially when the pharmaceutical profits are soaring. That's the take-away message."

"It is disappointing that Gov. Brown has decided to sign a bill that is based on misleading rhetoric instead of what's in the best interest of patients," said Priscilla VanderVeer, spokeswoman for the Washington, D.C.-based Pharmaceutical Research and Manufacturers of America. She added that there is "no evidence that SB 17 will lower drug costs for patients."

The bill does not actually control drug prices, leading some critics to suggest it is toothless. However, the bill's backers say that transparency in other health care sectors has been successful in reducing costs. Anthony Wright, executive director of Health Access California, agreed. He said the advance notice and information required under SB 17 "is invaluable" to large health care purchasers such as insurers, union trusts and employers, and would enable them to drive a better deal for consumers.

Brown also signed a related bill on Monday. Assembly Bill 265 will prohibit prescription drug manufacturers from offering discounts for name-brand drugs, if a less-expensive equivalent brand is available, preventing the use of higherpriced drugs when unnecessary.

Richard A. Robbins, MD

Editor, SWJPCC

\section{References}

Seipel T. Gov. Brown signs drug pricing transparency bill. The Mercury News. October 8, 2017 (updated October 9). Available at: http://www.mercurynews.com/2017/10/08/gov-brown-to-sign-drug-pricetransparency-bill/ (accessed 8/10/17). 